\title{
Interventi
}

\section{The Kelabit attitude to the Penan: forever children}

Monica Janowski

The Kelabit homeland at the headwaters of the Baram river is one dominated by forest. A human enclave has been carved out of the primeval forest through agriculture, which has tamed and controlled a small piece of the natural environment. Nevertheless, Kelabit agriculturalists in this environment traditionally relied heavily on the forest as the source of much of their food, building materials and materials for handicrafts.

Rice is the focus of Kelabit agriculture. There appears always to have been a distinction between the type of rice agriculture practised in the area now known as Bario in the north of the Kelabit Highlands ${ }^{1}$ - and probably, in the past, in other sites south-west of Bario - on the one hand and that practised in other parts of the Highlands. In the Bario area only wet rice fields (late baa) were made, in conjunction with gardens (ira) in which other crops were grown. In other parts of the Kelabit Highlands dry rice fields (late luun) were made, in which other crops were planted together with the rice. Both late luun and late baa were impermanent fields; they were shifted regularly from place to place. Everywhere in the Highlands, there appears to have been a similar reliance on the forest as the source of a large proportion of vegetables eaten with rice at the rice meal, of fruit, and of protein food. The fact that there was no permanent agricultural area in the past must have heightened the sense of dependance on the forest.

In the early and mid 1960's there was a resettlement of a large proportion of the Kelabit population to Bario. This occurred at the time of the 'Confrontation' with Indonesia. It was linked to a shift to dependance on permanent wet rice fields in the Bario area. An airstrip had already been built at Bario from which there were regular scheduled flights to Marudi and later to Miri as well. At the time of the resettlement and soon after, government services came to be concentrated at Bario - schools, clinic, administrative offices. Because of this, the people who came to Bario because of the Confrontation did not return to their original homes but remained in Bario. Indeed, since that time migration to Bario from other Kelabit communities has continued.

Reliance on rice cultivation continues to be heavy in Bario. It has, in fact, acquired an added dimension: certain of the varieties (known in the Highlands as pade adan and pade dari) grown in wet rice fields in the Kelabit Highlands can be sold at high prices on the coast and these are therefore exported to the coast by air, generating substantial income. However, although late baa now cover a large area at Bario, there is inadequate land for the making of ira gardens, and therefore supplies of cultivated foods other than rice are inadequate.

Reliance on the forest has decreased in Bario since the 1960's. The heavy concentration of population in the Bario area - where there are eight longhouses and a population of perhaps a thousand - has meant that there are not adequate forest resources for all. Forest - both primary and secondary - is now further away, and what forest resources exist are far too small to provide the level of unmanaged resources to which the Kelabit are accustomed elsewhere in the Highlands.

Foods can be brought in by air into Bario to make up for the shortage of wild foods and of cultivated foods other than rice. However, such imported foods, although prized as associated with status because money is used to buy them, are not acceptable as full replacements for wild foods or cultivated vegetables and fruit. Most of these foods are tinned or packet, not fresh. It does not appear to be considered acceptable to eat only such foods with rice at the rice meal; efforts are made to collect wild plants to cook as vegetables at the rice meal. Meat is a particular problem. Traditionally, domestic animals were only slaughtered for irau feasts, and even today almost no animals are slaughtered for the sale of their meat for everyday consumption. Meat is very rarely brought up from the coast. Bario people are always very keen to buy meat from wild animals brought in by men from communities outside the Bario area, and high prices (by Highlands standards) are paid for this meat. However, despite shortages and the import of foods, a large proportion of food in Bario - perhaps a third of the foods consumed as side dishes at the rice meal and a quarter of snack foods - continues to be wild.

In the community of $\mathrm{Pa}^{\prime}$ Dalih in the southern part of the Kelabit Highlands, where I did fieldwork from 1986 to 1988 and again in 1992-3, the traditional reliance on the forest has changed little. The forest has remained a great provider. Almost no food is brought in from outside. Seasonings and sugar make up the majority of foods from town.

The Kelabit eat food in two main contexts: at the rice meal and as snacks. Snack foods include meat eaten on its own, fruit, starch foods other than rice (mainly maize and cassava) and sugar 
cane. The eating of snack foods is a casual matter; they are freely shared and casually eaten with little significance being placed on who provided them and without the pattern of consumption having any social consequences.

The rice meal (kuman nuba', literally 'eating rice [in the form in which it is cooked for the rice meal])', on the other hand, consisting of rice and of side dishes (penguman) - literally 'something to eat with (rice)', is loaded with significance. It is normally consumed within a hearthgroup, the basic commensal unit. This unit is more or less the equivalent of the Iban bilek (Freeman 1955). If it is shared with members of other hearth-groups, this has important consequences in terms of the generation of status. It is the consumption of the rice meal which is considered to truly nourish. Should a person be hungry, they must 'eat rice' (kuman $n u b a^{\prime}$ '). Snack foods are not supposed to be eaten to satisfy hunger.

The Kelabit reliance on rice as staple starch food is more apparent than real in nutritional terms. In practical fact, a very large proportion of the calories consumed by the Kelabit, perhaps up to one-third, is provided by starchy snack foods. However, to the Kelabit it appears that rice is the major starch staple upon which they rely.

Rice-growing appears to the Kelabit as the only feasible way of life. They reject the possibility of any way of life other than one which focuses on the cultivation of rice. The fact that they have rarely been forced to resort to root crops to bulk out their rice due to a bad rice harvest, as many other Borneo groups are forced to do, is a matter of great pride to them.

The Kelabit are particularly insistent in their rejection of hunting and gathering as a way of life. However, the presence of the hunting and gathering Penan in their immediate environment means that hunting and gathering, as a possible way of life, is constantly before Kelabit eyes. It makes their choice of rice-growing as a way of life a much more real choice, in fact, since it is clear that it is not the only possible one.

Despite the Kelabit rejection of hunting and gathering as a way of life, there is no doubt that the Kelabit rely heavily on the forest. About half of the plants which they utilize to make side dishes for the rice meal are wild, all the meat which they cook as side dishes on an everyday basis is wild, and about half of the fruit which they consume is wild or semi-wild (planted at some time in the past but then abandoned to grow in what has become forest).

Without side dishes, a rice meal cannot be a rice meal. These side dishes consist of cultivated or wild vegetables and of wild meat. A very large proportion of food in such side dishes is wild. Even cultivated vegetables are grown in a way which tends to equate them much more with wild plants than with rice, and to associate them therefore with the forest. Thus, the rice meal contains within itself a reliance on foods from the forest.

However, this undeniable reliance on the forest is veiled, publicly. The rice meal, which in fact consists of rice together with side dishes, is described as kuman nuba', 'eating rice'. This reflects the pivotal significance of rice as a crop and as a food. Rice symbolizes true human food.

To the Kelabit, the successful growing of rice and its consumption at the rice meal may be said to represent ulun, which can be translated as 'true human life'. For the Kelabit, only humans can 'have life' (inan ulun). Other animals 'live' (mulun) but cannot 'have life'.

Ulun, although it is something all humans have, is not something all humans have to the same degree. It is possible to have 'strong life' (kail ulun) or 'weak life' (kaya' ulun). The degree to which an individual attains ulun is related to the degree to which he or she attains full adulthood. Adults are termed lun merar, 'big people'. The word lun is cognate to the term ulun, and in fact I was told that to describe someone as being lun merar or as having ulun merar amounts to the same thing.

Being an adult, lun merar, has as its prerequisite being a member of a couple and involves three things: the successful growing of rice together with one's spouse; the birth of children and of grandchildren; and the feeding of children and grandchildren at the rice meal.

Not to cultivate rice does not mean starvation. There are many other foods available, including very productive starch foods such as cassava root. It means loss of lun merar-hood. It means being described as having 'weak life'. Rice-growing is represented as difficult, as likely to fail, as requiring constant attention and assiduity to ensure its success. It is the 'difficult' option.

An examination of Kelabit attitudes to hunting and gathering makes it quite clear that, to them, this is a way of life which is paradigmatically pleasant. In contrast to rice-growing, hunting and gathering is the 'easy' option. It represents the achievement of nothing in terms of social adulthood, lun merar-hood. It is something to indulge in, rather than an accomplishment to be proud of. This is despite the fact that hunting, in particular, is an extremely strenuous activity.

In $\mathrm{Pa}$ ' Dalih, everyone, both men and women, young and old, is involved very regularly in economically productive activities, including hunting and gathering of food, in the forest (polong). Men hunt for meat and fish and gather other protein food in both the primary forest (termed polong raya, literally 'big polong') and the secondary forest (termed polong $i$ 'it, literally 'little polong'), while women gather vegetables on a daily basis in the 'little polong' and in amug (growth of up to about three years on previously cultivated land). Thus productive involvement with the forest is very pervasive throughout Kelabit society.

However, while all individuals involve themselves in this productive relationship with the forest, only 'big people' (lun merar), involve themselves properly in rice-growing. 'Big people' involve themselves much less in hunting and gathering than do individuals who do not yet have children nor involve themselves properly in rice-growing. Once a couple is married and has had a child, they limit their involvement with the forest more and more. Although the husband continues to hunt and the wife to gather, this is increasingly something to be done in the interstices of rice-growing. The cultivation of rice becomes their focal activity.

The process of distancing oneself from the forest and of developing a growing association with rice growing is a gradual process and reaches its peak when the couple is in their early forties, when they tend to take responsibility for their own rice-growing and cease to be merely the helpers of the older generation couple within the hearth-group in which they are resident. It is at this point that a couple becomes grandparents, and this status may 
be said to mark the culmination of 'big person'-hood. The process is marked by the holding of irau, feasts, at which parental and grandparental names are taken which mark not only the parenthood and grandparenthood of the individuals concerned but also their success in rice-growing, stated through their provision of a rice meal for the guests.

The young, anak adik, on the other hand, those who are not married and do not yet have children, are free to spend a good deal of their time hunting and gathering, and pressure is not put on them to help in the rice fields (late) - although girls may help in the fields and are expected to help in the processing of rice and in cooking rice meals so that their parents can spend as much time as possible in the rice fields.

The distinction between hunting and gathering activities and rice-growing and processing activities is made verbally through the use of different terms to describe them. Rice growing and processing is described as lema' 'ud, and is considered both onerous and admirable, the mark of a 'big person', a social adult. Lema'ud is considered difficult, something which one has to push oneself into. Hunting and gathering activities, on the other hand, are described as raut. This is the same word as is used to describe the play of children, and such activities are indeed considered fun, leisure, easy - despite the fact that hunting is actually extremely physically demanding and tiring, perhaps more so than rice-growing. Hunting and gathering activities, as 'play', are considered so pleasant that they exert a strong magnetic pull, and the weaning of a young person off of them on to rice-growing activities, lema'ud, as he or she becomes a 'big person', is seen as difficult. This is particularly true for young men, who are strongly associated with the forest.

Thus, lema'ud, the term used to refer to rice-growing activities, refers to activities appropriate to social adults, 'big people', lun merar. Raut, which can be glossed as 'play' and which describes hunting and gathering as well as children's play, refers to activities appropriate to those who are not social adults, who are not parents and who do not produce rice. Rice-growing, then, is associated with adulthood, while hunting and gathering are associated with immaturity.
The fact that Penan do not engage in rice-growing traditionally but subsist solely from hunting and gathering associates them with Kelabit anak adik. Rather than taking on the burden of lema'ud, rice-growing 'work', as is appropriate for those with children, even Penan adults prefer, as the Kelabit see it, the easy life of relying solely on the forest for their subsistence. They are, in effect, refusing to accept the transition to adulthood which Kelabit children have to make once they have children of their own and must become social adults, 'big people'.

For the Kelabit, it is arguable that Penan are, in 'refusing' to become ricegrowers, 'refusing' to become responsible for others. Successful rice-growing, for the Kelabit, has as its end product the ability to provide for others, dependants, through the provision of the rice meal. The social adults, the 'big people', of a hearth-group, make the rice meal possible through their production of rice. The 'big people' are, through what might be termed the regular 'performance' of the rice meal, legitimising their status as parents and grandparents. It is the provision of the rice meal for children and grandchildren which is generative of the status of 'big person', of social adult. Should a couple, established parents and perhaps grandparents, prove unable to grow enough rice to provide for their hearthgroup, they cannot be seen as 'big people' despite their children and grandchildren. They would in the past have been forced eventually to become the dependants, perhaps even the debt-slaves, of the 'big people' of another hearth-group (LianSaging 1976/77:123). It is because anak adik, those who are not married and do not engage in rice-growing, cannot provide rice meals for others that they are not 'big people'.

The status of 'big person' is the basis of the system of differential prestige among the Kelabit. It is through the provision of the rice meal that prestige is generated. At the level of the hearth-group, basic prestige is generated through the proven ability of the 'big people' of the hearth-group to grow enough rice to provide the rice meal three times a day. However, prestige of a higher order is also generated through the provision of rice meals for higher, symbolic-level hearth-groups. It can be argued that groups larger than the hearth- group - the longhouse, the multi-longhouse community and the whole Kelabit population - are stated at certain occasions - all commensal meals - to be equivalent to a hearth-group. At certain of these commensal meals, these symboliclevel hearth-groups are provided for - in terms of the provision of the rice meal by the 'big people' of the hearth-group which hosts the meal. These people are thus presented as being the 'big people' of the symbolic-level hearth-group which is generated through the holding of the commensal rice meal. The most important of these occasions is irau mekaa ngadan, naming feasts, when the 'big people' of the host hearth-group publicise their status as reproducers of children and grandchildren and as successful rice-growers through the provision of a rice meal for the whole of the Kelabit population, or for as large a proportion of it as accept the open invitation to attend.

The symbolic equivalence of the status of 'big person' of a hearth-group and 'big person' of a symbolic-level hearth-group is reflected in the use of the same term to describe those of high status in society, the leading couple of a longhouse, and the 'big people' of a hearth-group. The leading couple of a longhouse community is still often described as the lun merar of the community, although the term tua kampong, used by the government is also current now. This couple appear to be, in a sense, the providers of rice for the whole community. There is a sense in which the leading couple of the longhouse, the 'big people' of the central hearth-group, are presented as responsible for the rice production of the whole longhouse. They are, as in other Borneo tribal groups, be the ones to begin the rice year and their opinions regarding rice-growing count for most. Should other hearth-groups' rice crop fail, they should be able, through the rice stocks which they must have in order to legitimate their status, to provide for other hearth-groups short of rice, particularly those of least status. The members of such hearth-groups were in the past known as anak katu, 'children of the end' (i.e. living at the unprestigious ends of the longhouse). The implication that such people were not adults but children is significant, and resulted from their inability to provide for themselves and their own hearth-groups adequately in terms of rice. 
They were the 'children' of the leading couple. Thus a leading couple put themselves in the position of 'big people', providers of rice for and symbolic parents and grandparents of, other hearth-groups in the longhouse community of which they were leaders.

The use of the term doo - 'good' - to describe both those 'big people' who are able to grow enough rice to provide the rice meal on an everyday basis for their children and dependants, and those who are prestigious in society also reflects the fact that it is the status of 'big person' which is the source of differential prestige within Kelabit society. Respectable social adults, fully able to provide rice meals for their own dependants and children, are described as doo; those who are able to provide lavishly for a higher, symbolic-level hearth-group at irau and have some left over to purchase prestige possessions - in the past, beads, gongs and jars, nowadays beads and townmade goods - are described as 'really good people', lun doo to'o.

The Penan, who do not grow rice, cannot generate differential prestige in $\mathrm{Ke}$ labit eyes. They could never be described as doo, 'good'; at least not while they are still nomadic and do not grow rice.

The Penan share all their food (Needham 1953), as the Kelabit share wild foods, including wild plants and meat for side dishes at the rice meal. Such sharing does not, for the Kelabit, amount to providing for others, as does the rice meal, however. For the Penan, such foods are appropriately shared: 'The hard things we worked for, the food we just found', they say (ibid: 134). The Kelabit attitude to such foods is similar. The sharing of wild foods - and of cultivated plants other than rice, which are treated in much the same way as wild foods - has no implications in terms of the generation of prestige, in the way that the provision of rice for others in rice meals held at irau does.

For the Kelabit, the fact that the Penan can generate neither social adulthood nor differential prestige - the latter stemming out of the former - means that they are not fulfilling their potential, as human beings, to disassociate themselves from the forest and to generate true human life, ulun. Although the Kelabit themselves traditionally relied a great deal - and, in communities like $\mathrm{Pa}$ ' Dalih, still rely - on the forest for much of their subsistence, it is rice-growing which they emphasize and value, seeing hunting and gathering as 'play'. For the Kelabit, rice cannot grow on its own, while all else can: 'Rice is the one essential item in Kelabit life which cannot come, go or grow of itself naturally. It has to be farmed or cultivated' say two Kelabit writers (Lian-Saging and Bulan 1989:102). Success in rice growing is, for the Kelabit, success in constructing something truly human out of the natural environment.

It is the cultivation of rice which is the supreme human achievement, which distinguishes humans from animals in the forest and which is generative of true human life, ulun. It is in the light of the above that the Kelabit belief that the Penan should settle should be understood. For the Kelabit, the settlement of the Penan means their taking up the cultivation of rice. This, in turn, involves the beginning of the generation of social adulthood, lun merar-hood and true ulun among the Penan. If they do not make the transition to settled rice agriculture, the Penan will remain, in Kelabit eyes, forever children: never thinking of tomorrow, 'playing' at hunting and gathering and refusing to take true responsibility - in terms of the provision of the rice meal for children and grandchildren, real and symbolic.

\section{References}

Lian-Saging, R. 1976/77, An Ethno-history of the Kelabit Tribe of Sarawak. A Brief Look at the Kelabit Tribe before World War II and after. Graduation Exercise submitted to the Jabatan Sejarah, University of Malaya [Kuala Lumpur], in partial fulfilment of the requirements for the Degree of Bachelor of Arts, Hons.

Lian-Saging, Robert and Lucy Bulan 1989, 'Kelabit ethnography: A brief report'. SMJ 61: 89-118 Special Issue No. 4, Part III. Orang Ulu Cultural Heritage Seminar held in conjunction with the 25th Anniversary of Independence.

Freeman, J.D. 1955, Report on the Iban, London School of Economics Monographs on Social Anthropology No. 41 London: The Athlone Press, University of London

Needham, R. 1953, The Social Organization of the Penan, a Southeast Asian People.Unpublished D. Phil. thesis, Merton College, Oxford University

\section{Notes}

${ }^{1}$ Until the 1960's the one settlement at present-day Bario was termed Lam Bah ('in the wet rice fields'). It seems that the term 'Bario' originated with Tom Harrisson, parachuted into the Highlands during the Second World War to organize resistance against the Japanese and later Curator of the Sarawak Museum. It may have derived from the term 'Lam Bah Ariu' ('in the windy wet rice fields') (Lian-Saging 197677:94). 